\title{
Saints and sinners: lessons about work from daytime TV
}

First draft article by Ursula Huws for International Journal of Media and Cultural Politics

\section{Introduction}

This article looks at the messages given by factual TV programmes to audiences about work, and, in particular, the models of working behaviour that have been presented to them during the period following the 2007-8 financial crisis. It focuses particularly, but not exclusively, on daytime TV, which has an audience made up disproportionately of people who have low incomes and are poorly educated: an audience that, it can be argued, is not only more likely than average to be dependent on welfare benefits and vulnerable to their withdrawal but also more likely to be coerced into entering low-paid insecure and casual employment.

It argues that the messages cumulatively given by 'factual' TV, including reality TV programmes ostensibly produced for entertainment as well as documentaries, combine to produce a particular neoliberal model of the deserving worker (counterposed to the undeserving 'scrounger' or 'slacker') highly suited to the atomised and precarious labour markets of a globalised economy. This is, however, a model in which there are considerable tensions between different forms of desired behaviour: on the one hand, a requirement for intense, individualised and ruthless competitiveness and, on the other, a requirement for unquestioning and self-sacrificing loyalty and commitment to the employer and the customer. These apparently contradictory values are, however, synthesised in a rejection, often amounting to demonisation, of collective values of fairness, entitlement and solidarity.

\section{The context}

Despite the explosive growth of the internet and multiplication of devices for accessing it, television remains the main means by which most people absorb narrative information. In 2013, $98.5 \%$ of TV was watched on a TV set in the UK information (BARB data, quoted by Thinkbox, 2014), where total average daily TV viewing was 4 hours a day in 2012, up from 3 hours and 42 minutes in 2004 (Ofcom, 2013: 179). This compares with only three and a half minutes of TV viewed on devices such as tablets, smartphones and laptops (ibid). Watching catch-up, free and paid Video on Demand (VOD) services accounted for only 8\% of all viewing time among UK adults in the first quarter of 2014 (Ofcom, 2014: 145). In a period when TV viewing and accessing digital content were remaining stable or growing, there was a sharp decline in accessing other forms of information. In 2010, less than half the adults in Great Britain aged 15 and over read a national newspaper (41\%), a continuation of the decline which has seen the proportion reading national newspapers falling by approximately 10 percentage points every ten years since 1981 . Between $2005 / 6$ and $2009 / 10$ the proportion of adults aged 16 and over visiting a public library in England fell from $48 \%$ to $39 \%$, whilst sales of books by UK publishers fell from 492 million books in 2007 to 463 million in 2009/10, a drop of 5.9\% (Seddon, 2011: 1).

The lower they are down the class scale, the more likely people are to watch TV, and to watch it in real time, and this bias is most pronounced during the day. In the USA, for instance, one study reported that $40 \%$ of daytime viewers earned less than US $\$ 20,000$ a year and $54 \%$ were educated to 
high school diploma level or less (Ault, 2001). The picture is confirmed by more recent US research from Nielsen (2011) who demonstrate a strong correlation between the number of years of education and the ownership of alternative means of accessing digital content, with only $35 \%$ of those with 0-3 years high school having digital media compared with $60 \%$ of those with four or more years college education (Ibid: 11). In 2010-2011, Nielsen found that household tuning had increased by more than an hour from the previous year, approaching eight and a half hours per day (ibid:15) and was significantly higher among Black and Hispanic Americans. Black Americans were tuned in for over 46 hours a week compared to 34.1 for 'composite' groups (those who were defined as neither Black nor Hispanic). (ibid: 20;22). The US Government Time Use survey (using a more conservative definition of 'watching TV') reports a similar picture. In 2013, those with less than a high school diploma watched on average 3.77 hours of TV on weekdays and 4.10 at weekends, whilst those with a bachelor's degree or higher watched 1.86 and 2.64 hours respectively. People defined as Black or African American watched 3.42 hours on weekdays and 4.25 at weekends, whereas those defined as white watched 2.47 and 3.14 hours respectively. Those who earned a full-time wage of less than US $\$ 520$ watched 2.93 hours on weekdays and 3.57 at weekends, whilst those who earned more than US $\$ 1,340$ watched only 1.90 and 2.45 hours respectively (Bureau of Labour Statistics, 2013).

TV audiences are, of course, heterogenous and there are undoubtedly major differences in their composition both within and between countries. Nevertheless, it is undoubtedly the case that there are large, and growing, numbers of disadvantaged people who are spending increasing proportions of their time watching TV in real time and, moreover, being relatively passive in this viewing in that they are most likely to be selecting from the available channels showing live at the time, rather than actively seeking out content. Despite their diversity, we can surmise that these people also have much in common. With diminished access to alternative sources of information, it seems likely that their world view is increasingly shaped by this viewing.

My main focus in this article is not on the multiple fictional programme genres, whether soap operas, crime, situation comedies or costume dramas, which undoubtedly play a strong role in shaping attitudes and attract considerable critical scholarly attention from people better qualified than myself to dissect them. Neither do I analyse the news, where the selection of stories and the spin put upon them clearly also plays a strong ideological role. Nevertheless, it has to be recognised that all these, along with commercials, game shows, childrens' programmes and the rest, form part of the larger ecology of television, interacting with each other in complex ways that both reinforce and challenge each others' messages. They cannot therefore be entirely ignored and are referenced where relevant below.

My primary emphasis is on 'factual' programmes, a category that includes various forms of reality TV and documentaries, and makes up a large and growing proportion of daytime viewing.

Documentaries (at 13.2\%) took the third largest audience share (after 'entertainment' at $17.7 \%$ and drama' at 17.6\%) of British viewing between January and September 2013. But perhaps even more significant was the fact that, whilst entertainment's market share had remained more or less constant since 2008, and drama's had dropped considerably, that of documentaries was growing strongly, and was, indeed, the only genre to have done so over the five-year period (BARB, 2013). As a proportion of total hours on the five main public service channels in the UK in (evening) peak time, factual programmes accounted for just over $30 \%$ in 2013 , only a small increase on previous years. 
But, during the day time it rose from $20 \%$ in 2007 to $28 \%$ in 2013 Over the same period, the category 'educational programmes' disappeared altogether (Ofcom, 2013: 172-3).

The growing importance of factual programming can be seen in the advice given by the BBC's commissioning editors to independent production companies wanting to pitch ideas for new programmes to them. The commissioners of content for daytime and early peak viewing for BBC1, for instance, first emphasise the size of their audience (about 10 million people) and then go on to stress its diversity.

There is no generic daytime audience. It is very diverse - from the retired, to home workers, shift workers, housewives and students.

Overall there is a female bias to the BBC Daytime audience but $40 \%$ of the audience is male so ideas must take their needs and interests into account.

The BBC attracts an older audience in Daytime but this does not mean they should be underestimated. The success and appreciation of new genres introduced over the last few years on BBC ONE suggest an audience appetite for more challenging programmes.

The Daytime landscape has changed dramatically over the last few years. The audience now want high quality programmes during the day - an expectation driven by increased choice, the ability to time-shift and the availability of peak-time repeats on digital channels. (BBC Commissioning, 2014)

Under the heading 'What's been working well' they present their three most-watched programmes, two of which are factual: Saints and Scroungers and Rip-off Britain (the third is a game show). They say they are looking for more such programmes:

We are looking for new half hour or 45 minute formats that engage the audience... shows need to feel realistic, but still have a generally positive tone and it is important that formats have some form of resolution. (BBC Commissioning, 2014)

They explain the success of Saints and Scroungers in these terms:

One of our successes in this slot is Saints and Scroungers. In this format Dominic Littlewood looks at the work of fraud investigators who bring benefit thieves to justice and he meets the genuine claimants who deserve government help. The series has great access to compelling stories, footage and contributors. Whilst money is central, there is a sense of justice and revelation about what people are actually entitled to at its heart, making the series feel real and relevant. (BBC Commissioning, 2014)

Such formulae are not unique to the BBC. Most notoriously, Channel 4 produced a prime-time fivepart documentary series called Benefits Street in early 2014 which provoked sufficient public outcry (based on what was seen as a demonisation and stereotyping of claimants) to force them to add an extra programme giving the participants a right of reply. Nevertheless, unrepentantly, the Channel 4 website is, at the time of writing, asking for volunteers to:

Appear in the next series. Benefits Street will return and we would like to hear from other people on similar streets (Channel 4, 2014) 
This is perhaps unsurprising given that the series drew the Channel its highest ratings since 2012, at an estimated 4.3 million viewers, representing a $17.2 \%$ audience share, a share which rose to $23.8 \%$ among 16-34-year-olds watching TV at the time. (Collier, 2014).

Similar programmes on Channel 4 in 2013 included Skint ('Provocative and revealing documentary stories of how people survive without work' ${ }^{1}$ ) and How to Get a Council House. Channel 4 has also, since 2009, been bringing the UK version of US-originated Undercover Boss to British audiences.

A rival commercial channel, Channel 5, features Benefits Britain: Life on the Dole and in 2013, Channel 4 offered Benefits Britain: 1949 in which real-life benefit claimants from 2013 were subjected to the rules applied in the early stages of the British Welfare State, in 1949. This seems to have been a direct competitive response to a BBC prime-time reality show, Nick and Margaret: We all Pay your Benefits, also broadcast in 2013, in which benefit claimants were paired with people with low-paid jobs. The BBC also showed another documentary series in 2013, People Like Us, shot in a deprived area of Manchester, this time on BBC3, which, like Benefits Street received some press criticism for misrepresenting its participants.

The growth of such programming, and its success in attracting audiences, comes at a time when the UK is facing unprecedented cuts in welfare spending and growing poverty, accompanied by extensive casualisation of work. A few statistics serve to give an indication of the scale of these changes. A 2013 report (Duffy, 2013) analysed the impacts of the Governments plans to cut public expenditure by $\mathrm{f} 63$ billion (a reduction of 10.8\%) by 2015 and found that the majority targeted two areas: benefits, and local government. Bearing in mind that $60 \%$ of local government expenditure is on social care, this means that people in poverty and the disabled are disproportionately affected by these cuts, with people in poverty ( $21 \%$ of the population) bearing $39 \%$ of all cuts and disabled people ( $8 \%$ of the population) bearing $29 \%$ of all cuts (Duffy, 2013). Meanwhile, the number of people in the UK relying on foodbanks to avoid starvation in 2013-14 was 913,138 - up from 346,992 in 2012-13, 128.697 in 2011-12 and 61,468 in 2010-2011 (Tressel Trust, 2014). In the labour market, the story was equally grim. In February 2013, the UK Office of National Statistics disclosed that real wages had fallen back to 2003 levels (ONS, 2013). A year later, they announced that 1.4 million workers in the UK were now employed on zero-hours contracts (ONS, 2014).

It is the relationship between this socio-economic context and the growth of such programmes, and their American equivalents (many of which are shown on British TV) that is explored in this article.

\section{Methodology}

I must, however, begin with a disclaimer. This article is not the result of a formal research project. It came about as a result of a more or less accidental collision between my formal research interests (in the restructuring of labour markets, the casualisation of employment and the growth of poverty ${ }^{2}$ ) and my personal circumstances. From 2006 to 2013, as the result of a slowly worsening health condition, I had to undergo occasional medical treatment that left me very tired and debilitated, requiring stretches lasting two or three weeks at a time spent in bed, too exhausted to do any

\footnotetext{
${ }^{1}$ http://www.channel4.com/programmes/skint

${ }^{2}$ At the time of writing, I am editing the journal Work Organisation, Labour and Globalisation (see http: www.analyticapulications.co.uk), leading a COST Action on the Dynamics of Virtual Work (see http://dynamicsofvirtualwork.com/) and participating in an EC-funded research project on the resilience of poor households in response to financial crisis (see: http://www.rescueproject.eu/).
} 
serious work or even read, during which I spent much of my time drifting in and out of sleep, remote control at hand, with the television as a main source of distraction and entertainment. During the daytime, in particular, there was little that grabbed my attention so I spent a lot of time cruising from channel to channel in search of something watchable. I was astonished both by the number of channels available ${ }^{3}$ and by the repetitive nature of their content and the frequency with which similar themes recurred. My immersion in this experience was periodic - on average three times a year - giving me some sense of the cumulative changes taking place in the balance of content and broader viewing trends: the declining interest in Big Brother over the period, for instance; the growing importance of shows like America's (or Britain's) Got Talent and their many imitators and spin-offs; and - the trigger for writing this article - the seemingly inexorable rise of 'factual' programmes following people about their daily lives. Exposure to such a large number of programmes, embedded in the broader context of unselective real-time television viewing, is, I suspect, quite a rare experience for an academic researcher, simply because the daily routine of combining teaching, research, attending conferences, writing and administrative work with managing some sort of personal social life that is normal for university employees does not allow time for it. For me the experience was certainly novel, and eye-opening.

I did not take a scientifically-justified random sample of programmes, nor did I take systematic notes. My analysis cannot pretend to be a rigorous textual analysis of their contents. Neither does it involve any systematic application of theoretical approaches to understanding how media messages are communicated, such as Hall's (1973) 'encoding/decoding' approach. I did not, after all, study anyone's responses to these programmes other than my own. Are other viewers indignant or amused or bored? Do they identify with the characters, love them or hate them? How does this vary by gender, ethnicity and class? Do they discuss them after the event and if so with whom? Do they concur with the 'message' of the programme expressed in the narrator's script or are they throwing their slippers at the screen in frustrated disbelief? I have no way of answering any such questions. Some indirect forms of 'hard' evidence can, however, be drawn on. These include the results of audience polls, such as the one Channel 4 quotes on its Benefits Street website: 'Of those who took part in our web poll and answered the question "Does the current benefits system discourage work?" 73\% said yes and 27\% said no' (Channel 4, 2014). Broader evidence from large public attitude surveys can also be cited. For instance, an analysis of results from the British Social Attitudes Survey between 1983 and 2011 found that:

Public support for extra spending on all types of welfare benefit has declined since the late 1990s with, in many cases, much of this decline being very recent (since 2008). The largest decline has occurred among those choosing extra spending on benefits for disabled people who cannot work, which has dropped by 22 percentage points since 1998, and by 10 percentage points in the last three years. (Clery, Lee \& Kunz, 2013: 32)

And:

\footnotetext{
${ }^{3}$ At the beginning of this period I had a subscription to Sky satellite services. From 2010, after a house move, I ended up with a Freesat satellite dish, giving a somewhat reduced range of channels. It is possible that this switch affected my impressions of the range of programmes available but I doubt it. The only losses I can recall were of channels showing repeats of old situation comedies, blokeish quiz shows and crime series.
} 
In 2011, negative perceptions of welfare recipients were held by considerable minorities of the population, with those in receipt of unemployment benefits being viewed negatively in terms of their ability to find a job by a majority. Slightly more than one third agree that most people on the dole are fiddling (37\%) and that many people who get social security don't really deserve any help (35\%). More than half (56\%) agree that most unemployed people in their area could find a job if they wanted one. (Clery, Lee \& Kunz, 2013: 39)

But of course no causal relationship (in either direction) can be drawn between such attitudes and the TV viewing of the people who hold them.

To the extent that this exercise can be regarded as serious research, its value lies in the interplay between my personal reactions to these programmes and my professional knowledge, as a sociologist of labour and poverty, of the empirical realities they refer to. In particular, this knowledge made me alert to inaccuracies and distortions in the way that 'facts' were presented in these programmes and the extent to which the people singled out for documentary attention were in fact typical or representative (in a statistical sense) of larger populations.

Aware of the dangers of selective recall, once I had decided to write this article, I tracked down the programmes whose names I could recall or recover by Googling and watched them again online, either from the broadcasters' own websites or on Youtube. In the case of series still running (including Saints and Scroungers, Fake Britain, Benefits Britain: life on the dole, and Undercover Boss, UK) I made a point of watching current episodes in real time.

In presenting the results of this process I have tried to situate the messages in their broader context, to identify the contradictory ways in which these may be reinforced or challenged by the dominant values of television taken as a whole. My aim in doing so is not so much to draw definitive conclusions as to map out areas that future research could investigate more systematically.

\section{What representations of themselves and their lives do people see on television?}

Whilst, as already noted, it is dangerous to assume that daytime television audiences are homogenous, it is nevertheless safe to assume that, compared with the population at large, they are more likely to be poor, disabled and unemployed. This also means that they are more likely to be hungry and poorly housed. They are, in short, more likely to belong, in the terminology of the right, to the 'underclass' (Hernstein \& Murray, 1994) or, of the left, the 'lumpenproletariat' (Marx, 1945) or, more recently 'precariat' (e.g. Standing, 2011).

It is useful to start by asking how people in this category see themselves represented on television. Leaving aside the fictional representations in soap opera or drama, it is striking that (with some significant exceptions to which I will return) they are overwhelmingly represented in factual programmes via the, often judgemental, mediating voices of professional middle-class commentators, with whom viewers are encouraged to identify.

In the genre of tabloid talk show hosted in the USA by Jerry Springer and in the UK by Jeremy Kyle, for instance, members of poor households are encouraged to act out the most extreme aspects of their dysfunctional relationships in front of a live studio audience. Far from empathising with them, viewers seem expected to join in with the orchestrated cat-calling audience in condemning the 
behaviour of those who are signalled as 'bad'. Judge Judy (in the USA) and her UK equivalent, Judge Rinder, pass judgement in a more formalised way, with more ridicule and less pretence of concern for the victims. Lives are viewed voyeuristically from the outside and what might in other circumstances be regarded as cruelty is justified on double grounds: first, the participants are there voluntarily (and, perhaps, by implication, culpable of showing off and/or being in it for the money even if they have committed no other offence); and second, they have been judged by a middleclass expert (who is also the audience's avatar) as bad, and are therefore deserving of punishment. There is an atavistic appeal here to motives not unlike those that brought crowds in earlier periods to watch public hangings or visit Bedlam to laugh at the lunatics.

This kind of psychological voyeurism is matched, if not exceeded, by physical voyeurism. It is rare for the dedicated channel-hopper not to come across at least one documentary about someone who is so obese that they have to be winched from their home into a truck in order to be conveyed to hospital for treatment that might (or might not) be life-saving, or a series in which a fat family is reeducated by a patronising 'expert' on how to change its lifestyle in order to lose some weight. Again, the voice of an intervening authority encourages us as viewers to dissociate from any identification with or empathy for the participants and give rein to our curiosity and disgust. Although here the commentators generally pay some lip-service to compassion, it is clear too that sharp judgements are being made about those participants, who are presented, at least implicitly, as greedy, lazy, selfindulgent and ignorant. In the dichotomised value system in which society is divided into saints and sinners they are, by and large, sinners.

Programmes about body weight, of which there are many, have to be seen within a broader continuum of programmes dealing with eating and food. Here, it is worth pointing out that a high proportion of viewers are likely to be watching television whilst actually hungry. A 2013 study carried out in London found that:

Over 70,000 children in London go to bed hungry sometimes or often.

Two-in-five (42\%) parents have cut back on the amount of food they buy in the past year. $9 \%$ of children (the equivalent of 74,000 children across London) said that they sometimes or often go to bed hungry. $44 \%$ of children in inner-London live in low-income households, highlighting the potential scale of child hunger should circumstances worsen. One-in-five parents (21\%) have skipped meals so that their children could eat, while $8 \%$ told us that their children have had to skip meals as there was not enough food to eat. $15 \%$ of parents report that their children always or often tell them that they are hungry. (Ipsos MORI, 2013:8)

Research also shows that watching food-related programmes stimulates the appetite and makes people consume more (Bodenlos \& Wormuth, 2013), including when they are dieting (Shimizu \&. Wanskik, 2011). It is therefore likely that a significant proportion of viewers are watching television in a state of hunger, or at least one in which there is a complex and perhaps conflicted relationship with their appetites. So what are these hungry people presented with? First, a large amount of advertising. One study, carried out in 13 countries and focusing on channels most watched by children, found that food advertisements composed between $11 \%$ and $29 \%$ of all advertisements, but that noncore foods (defined as those high in undesirable nutrients or energy as defined by dietary standards) were featured in between $53 \%$ and $87 \%$ of these (Kelly et al, 2010). On British television, these advertisements range from seductively - indeed, almost pornographically - 
presented images of food as luxury, as in various chocolate advertisements and the Marks and Spencer Not just Food series, (famous enough to be the subject of a semiotic study by Tressider [2010]), conveying a 'go on - indulge yourself' message, to those in which fast food is presented as the centre of family treats, or fuel for the hungry worker on the go. Interspersed with these are a very large number of programmes featuring cooking. Some of these purport to educate, others are competitions and yet others are ostensibly documentaries, like Channel 4's much-repeated, Come Dine with $\mathrm{Me}$, in which the viewer is expected to identify with the detached and mocking voice of the show's sardonic narrator, Dave Lamb, making fun of the social aspirations of the volunteer participants (but nevertheless providing detailed recipes for all the dishes).

Taken together, these present the viewer with a range of contradictory messages to which the most rational response (for those who can afford it) is bulimia. Food is presented (by advertisers, television chefs and other expert voices) as enticing and delicious. Preparing the right food is an art that brings to those who are proficient at it a whole string of rewards: the love of their families, the approval of health gurus and dieticians, high scores from snobbish co-contestants and, the ultimate accolade, a place in the final of a competition show like Masterchef or The Great British Bake-off. But preparing and eating the wrong food is sinful in the extreme: putting at risk one's health and that of one's family, damaging the environment and demonstrating the greed and lack of restraint that can only lead, eventually, to becoming an exhibit on an obesity freak show. The distinction between good and bad food is a tricky and shifting one. At the posh end of the Food Channel's scheduling, Nigella Lawson simpers and pouts seductively as she urges viewers to indulge themselves with expensive high-calorie ingredients while her somewhat down-market, and even chubbier, Transatlantic counterpart, The Barefoot Contessa, presents even more calorific recipes (generally involving the combination of large quantities of cream and sugar in a food processor), the results of which are then consumed in the company of a group of appreciative guests (in the process providing a model for would-be Come Dine with Me contestants about what a dinner party should look like). Another Food network regular from the USA is Diners, Drive-ins and Dives, featuring the commercialscale preparation (and enthusiastic consumption) of a range of deep-fired, over-salted, over-cheesed comfort foods. Other TV chefs present food either in dedicated cookery programmes or as hosts or guests of daytime chat shows. Their styles are different but they are often framed similarly. They start by disparaging ready-bought meals, or traditional ways of preparing unloved or boring dishes. Then they promise to show you a new and exciting way of producing a much better home-cooked version in a form that will be cheaper, more delicious and more nutritious (or more authentically French, Italian, Chinese, Indian or whatever other cuisine is being presented). Whilst described as 'simple' it will involve a large number of ingredients, some of which will only be used in very small quantities ('just a drizzle of sesame oil', 'just a splash of brandy', 'just a handful of fresh basil', 'just a scrape from a pod of vanilla'). Concessions are made to the poorer viewer: 'if you haven't got any pancetta, bacon will do instead', or 'you could substitute plain white wine vinegar if you don't have balsamic', or 'it would be OK to use dried pasta instead of fresh' but there is a clear implication that the flavour will suffer. There is normally a lot of waste. A whole lemon may be cut up in order for part of it to be squeezed carelessly by hand into a dish; the green ends of the leeks will be discarded; the fat will be cut from the meat. For viewers with empty cupboards, or brought up with post-War food rationing, this is shocking.

Recently some programmes, such as Jamie's Money Saving Meals and SuperScrimpers, have attempted to adjust to the realities of rising food prices and growing food poverty by presenting 
cheap recipes. Whilst cheaper than normal TV fare, these generally assume a cupboard full of extra condiment. Many feature cheap cuts of meat, such as ox tail and pigs feet which require long slow cooking - completely ignoring the high cost of energy that means that in reality many poor families keep cooking to an absolute minimum. The most recent Jamie Oliver programme (broadcast on July $7^{\text {th }}, 2014$ ) features 'a thrifty pukka chicken curry, using chicken drumsticks - half the price of breast but with twice the flavour' for 'only $\mathrm{f} 2.30$ a portion' which is, we are told 'way cheaper than any takeaway'4.

But even $f 2.30$ would clearly be unaffordable for most claimants. The Telegraph (a conservative newspaper that supported the Coalition Government's Benefit Cuts) did some calculations in 2013 based on the $f 53$ a week a typical claimant would be entitled to and estimated that they would need to set aside at least $£ 5$ for gas, $£ 3$ for water and $£ 8$ for electricity out of this amount. As a condition of receiving benefit, an unemployed claimant would also be required to show evidence of active searching for work which would, at a minimum, require expenditure on a phone, estimated at $f 4$, and on travel, estimated at $f 13$ (Shute, 2013). The remaining $£ 20$ a week would of course have to cover many more things than just food, from clothes to toothpaste. So a viewer on benefit, watching Jamie Oliver, would still experience being provoked into hunger without the means to satisfy it.

The messages to the viewer here are complex. First, there is an implicit disparagement of what you are used to buying and eating. Then home cooking is presented as good, but only certain kinds of home cooking. However home cooking is also shown to require complex expertise and expensive ingredients ${ }^{5}$. Dominating all these, however, is the message that food is delicious, seductive and desirable. No dish is finished until a close-up has been shown of somebody putting it into their mouth and saying 'Mmmmm' - a message likely to trigger the appetite of any hungry viewer.

Counterposed against this set of messages in which food is delicious and desirable is another, very different one, presented by shows such as You are What you Eat, Supersize vs Superskinny, The World's Best Diet and, more indirectly, by a range of body makeover programmes such as How to Look Good Naked and 10 Years Younger. Here, food - or at least the wrong sort of food - is quite simply bad: making you unhealthy, obese and unattractive. Yet these two contradictory sets of messages have certain things in common with each other. Both denigrate the daily diet of poor people, and both set middle-class 'experts' in command of the narrative that decides, in whatever circumstances, what kind of eating is good, and what is bad.

As with food, so with other aspects of taste. Another programme genre that dominates daytime TV is the property show. Many (such as Location, Location, Location, Escape to the Country and A Place in the Sun) show purchasers being shown around houses for sale that are way beyond the means of most viewers. A variant, Under the Hammer, focuses on dilapidated properties being sold at auction whose purchasers are then followed through the process of developing them. The viewer is not shown these houses from the perspective of their current or former residents, whose taste is often mocked or derided as old fashioned ('well of course that 1980s kitchen would have to go'; 'you'd need to replace that outdated wallpaper') but from that of the potential purchaser. In Under the Hammer, the majority of these purchasers are property developers, presented sympathetically (if

\footnotetext{
${ }^{4}$ Watched on August 23, 2014 at http://www.channel4.com/programmes/jamies-money-saving-meals/ondemand/59015-006
} 
sometimes patronisingly) as hard-working entrepreneurs. At the end of each programme, estate agents are called in to evaluate their work: how much value have they added to the property by doing it up or, alternatively, what could be charged for renting it out? The results are calculated as a profit or percentage return on investment. At no point is the view of any tenant presented. Again, it is instructive to view this in the context of the current crisis in the British housing market. Results from the English Housing Survey indicate that there was a dramatic rise of $56 \%$ in private renting between 2004-5 and 2009-10, with over two-thirds (68\%) of new households formed in 2008-9 and 2009-10 living in the private rented sector. The average weekly rent in 2009-10 was $f 156$ for private renters, compared with $f 75$ for social renters (and more people now live in private than socially rented accommodation). An estimated $2.9 \%$ of households were overcrowded (Guardian, 2011).

A significant proportion of daytime television viewers are therefore likely to be unable to consider buying a home and to have a direct interest in finding one with an affordable rent. But they are offered no avatars on these programmes. Like the viewers of food programmes, they are merely shown enticing images of what is beyond their reach. The values of the market are presented not only as unquestionable and inevitable but also as something that smart people take advantage of, thus, perhaps, constructing those who do not as fools. In this context it is interesting to note how the word 'property' has come to replace 'home' in the estate-agent discourse that is adopted by the programme-makers and presenters. The significant exception - Homes under the Hammer - is the one which actually follows this logic most blatantly but, perhaps unconsciously, provides us with the most vivid metaphor for what is actually happening to working class homes and lives which are being 'hammered' under the rule of the market.

Reducing everything to its market value is not, of course, unique to the property programmes. It also features in another genre, exemplified by such programmes as Bargain Hunt, Cash in the Attic and Flog It! in which second-hand goods are sold, often at auction. Here again, when set against the broader television context, there are contradictory messages. On the one hand the objects passed down from parents and grandparents or stored in the attic are presented as things of value, often described as 'collectible'. Buying them as investments or cashing them in is therefore promoted as a logical way to generate some income. Here it is interesting to note that on the commercial channels these programmes are often punctuated with advertisements for companies that offer cash for gold or for old mobile phones, or offer quick loans at high interest, suggesting some awareness that there may be viewers in dire financial straits. However, in a bulimic pattern that echoes that of the food programmes, their messages must also be set against those of the many other programmes (such as The Hoarder Next Door and Britain's Biggest Hoarders) in which hanging onto possessions is presented as a pathological disorder which has to be cured by an expert - with part of the therapy generally involving throwing things out as garbage. 'Decluttering', by ruthlessly destroying the results of past labour and discarding treasured possessions, is also emphasised in other programmes such as Get Your House in Order, 60 Minute Makeover. Just as eating can be both 'good' and 'bad', so can owning and becoming attached to objects. If any consistent message is to be found, it is 'trust the (middle-class) expert'.

\section{Work values}

Some of these overarching themes can be found expressed more explicitly in relation to work values. Alongside the theme of the inevitability of the market, another neoliberal trope is consistently reinforced: the virtue of entrepreneurship. As well as being celebrated indirectly, as already seen, in 
programmes like Homes under the Hammer, entrepreneurship is directly promoted in programmes like Dragons' Den, where people pitch their business ideas to a panel of multi-millionaires in the hope of obtaining investment. Much more powerful than this foreground message, however, is the broader background context in which entrepreneurship is located: the competitive market.

The inevitability of competition, and, linked to this, the notion that there can only be one winner emerges as a central trope, cutting across all television genres. Whether it's a reality TV show like Big Brother, a cookery competition like Master Chef, a talent show like Britain's got Talent, or a children's quiz show, the message is the same: to avoid losing you have to ditch all solidarity. Much of the tension in these shows lies in the inexorable process by which, week after week, one competitor after another is eliminated (often with the collusion of the audience who are lured into complicity with the judges - and parting with cash - by voting for their favourites) giving the message to every viewer that you too could be a loser.

The link with work is most overt in The Apprentice, in which candidates are literally competing for a job, but the principle remains the same: if you want to get on, you have to submit yourself and your work for the approval of a panel of people whose judgement is final - just like a job interview. It is clear that this is not just a one-off process that takes place at the beginning of one's career. Several involve people who are already established, such as Great British Menu in which professional chefs compete against each other. In other programmes (for instance The Hotel Inspector, Mary Queen of Shops and Ramsay's Kitchen Nightmares), existing businesses are exposed to the critical scrutiny of 'experts', in the process, we are led to believe, giving the viewer helpful hints on how to avoid their mistakes (though, it should be noted, the credentials of these experts are not always strong).

Closer investigation, however, throws up another tangle of contradictions. Competition is lauded and entrepreneurs celebrated, but proprietors of small businesses are not always held up as heroes. There is another genre of programme (such as Fake Britain, Rip-off Britain, Cowboy Builders and The Sheriffs are Coming) in which they are portrayed as out-and-out villains, taking advantage of vulnerable consumers by selling them fake or shoddy goods, failing to carry out repairs or other scams. Here the role of the television presenter (often the ubiquitous Dominic Littlewood, who is unusual in having a strongly working class accent and a tough street-boy persona) is to expose the culprits whilst - in the case of Cowboy Builders, at least - restoring the damage they have done, leaving the viewer with the comforting impression of justice having been done.

These programmes are often made in collaboration with the authorities. The Sheriffs are Coming, for instance, is presented as a documentary following the work of High Court Enforcement Officers who are, in effect, public bailiffs, enforcing judgements made by High Courts and County Courts in England and Wales across a wide variety of cases. In this it has something in common with other documentaries about public service workers, such as A Life of Grime and The Planners, which followed the work of environmental health inspectors and planners respectively. However The Sheriffs are Coming is much more threatening in its language - conveying a strong message to viewers that they might be next in line for the aggressive attentions of the Sheriffs. As I write, the programme website ${ }^{6}$ is announcing the highlights of its current series including cases against a car dealer, a tattoo parlour, a dentist, and 'a stand-off with squatters who have jammed the locks and

\footnotetext{
${ }^{6} \mathrm{http}: / /$ www.thesheriffsarecoming.tv/
} 
shutters from the inside'. The line between the criminalisation of businesses and individuals is a fine one: even homeless people can be targetted by the Sheriffs.

What are the lessons here? First, competition is good, but only if it meets the criteria of the unelected and unaccountable judges who decide who the winner will be. And, of course, since there can only be one winner in any given contest then the majority of people will be forever losers.

Second, entrepreneurship is good - until the entrepreneurs are caught overstepping some line, in which case they are transformed instantly into villains. In this situation, in a reflection of the broader situation in a neoliberal world, a sudden flip-flop transition takes place: as the excesses of the free market are seen to have bad consequences, so the forces of the state become suddenly good.

\section{Saints and sinners}

This brings me to one of the dominant themes in the representation of work, and attitudes to work on UK television. This is the dichotomous polarisation of the working class into two categories: the 'Saints' and 'Scroungers' depicted in the programme of that name, fronted by consumer champion Dominic Littlewood (former presenter of Fake Britain and Cowboy Builders). The repeated message of this programme, and others like it, is that people in receipt of welfare benefits, are living a cushioned and idle existence at the expense of 'hard-working taxpayers'. This too is spelled out in a title, in this case, We all Pay your Benefits, a programme presented by Nick Hewer and Margaret Mountfort ${ }^{7}$, both previously associated with The Apprentice and with the promotion of entrepreneurship.

Before analysing the messages given by these programmes it is worth pointing out the faultiness of the premise on which they are based. In fact, by far the largest chunk of the benefits bill is paid, not to the unemployed but to people in work, mostly in the form of tax credits but also in the form of child benefit and housing benefit. Introduced by the New Labour Government elected in 1997, tax credits are paid to households whose earnings are insufficient to allow them to survive. They are, in effect, a subsidy by the taxpayer to the employers who pay below-subsistence wages. According to HM Customs and Revenue (2012) 5.8 million families, containing 9.3 million children, were tax credit recipients or were receiving the equivalent child support through benefits in April 2012. The number of such recipients rose sharply after the financial crisis, as a result of the squeeze on wages. In 20112012, job-seekers allowance, paid to unemployed people, accounted for only $4 \%$ of all benefit spending. The equivalent figure for tax credits was $27 \%$ ! (Guardian, 2013). The vast majority of benefit recipients are in fact precisely those hard-working people whose interests are usually counterposed to them. Objectively, both groups - those seeking work and those already employed have a common interest in higher minimum wages and the statement 'we all pay your benefits', if it has any validity, would be better addressed on their joint behalves (since unemployed people also pay a lot of tax on their purchases) to the employers who pay low wages, especially the many who evade the payment of corporation tax.

It is perhaps in no small part thanks to the efforts of the tabloid newspapers and the producers of factual television programmes that the British public has such a low awareness of this reality. As the survey results quoted above make clear, a great deal of mud appears to have stuck. Without quoting

\footnotetext{
${ }^{7}$ Their latest collaboration - Nick and Margaret: Too many Immigrants? suggests that they are moving further along the path of legitimating populist prejudices.
} 
extensively, it is difficult to overemphasise the virulence with which the message is pushed home that the majority of welfare recipients are undeserving. Saints and Scroungers specialises in exposing welfare fraud, with the full co-operation of public fraud officers who are followed as they investigate specific cases. In the two episodes I watched fully, the fraudsters were both black women. In each of these programmes, the counterbalancing 'saints' (deserving sufferers who are given extra help by the programme) where white. I cannot claim that this was necessarily representative, but this certainly did nothing to challenge racist stereotypes. There have also been one-off documentaries, such as Dispatches: Tricks of the Dole Cheats whose main argument is that people are claiming benefits when in fact they have other sources of income. As in Meet the Sheriffs, these programmes give a not-so-subtle message to the viewer that the authorities will come and get you too if you transgress. The picture of widespread benefit fraud these programmes present is completely at odds with the reality, in which 'only about $1 \%$ of all benefits are fraudulently claimed. Indeed more money is lost through administrative error than benefit fraud' (BBC, 2010).

Alongside this is a contrary discourse that presents claimants not so much as tricksters but as idlers. On Benefits and Proud, focuses on people who were previously claiming sick benefits but under new regulations have been assessed as fit. This is also the main theme of Benefits Britain and various other programmes. The message is conveyed both visually and through language in a manner that could only be adequately illustrated by lengthy quotations. I give only a few vignettes here. In one, On Benefits and Proud presents figures about the number of people who are claiming sick benefit because they are unable to work over images of people playing golf, running after a football and dancing ${ }^{8}$. An episode of Benefits Britain ${ }^{9}$ shown on July 21, 2014 interwove three stories: a woman with eleven children ('in line for a new home many taxpayers could only dream about'), two young single mothers ('in one of the most expensive parts of London') and a family in Liverpool. This family is described as 'expert' in claiming benefit - 'their only hard graft is working the system'.

Throughout the programme, all the families are shown enjoying themselves, as though this is in itself somehow a sign of undeservingness. The camera lingers on details that are clearly supposed to be regarded as luxuries - a new television, people smoking, young single mothers getting their nails done and trying on hats in a street market, pets. In one scene the small son of the Liverpool parents is shown with his mother feeding birds in the street outside their home. This harmless activity, which might even be regarded in another context as 'spending quality time with the child', is presented as wasteful. 'Having fattened up the pigeons, now it seems to be the turn of daughter Charlotte', says the commentator, linking to the next sequence, where the vitriol is redirected at the extended family. Attitudes that would be praiseworthy in middle-class families, such as wanting to spend time with their small children, or taking a pride in their appearance, are routinely condemned. Even a close up of one of the single mothers cutting up fresh vegetables (which would undoubtedly be commended as 'preparing a cheap and healthy meal' on any other programme) is accompanied by a sarcastic commentary: 'despite their cooking skills, Sophie and Emma have no qualifications'.

The emphasis on appearance is also evident in a Daily Mail review of Benefits Britain 1949, when it describes one of the participants in these terms: 'Strikingly, Karen, who is very overweight, has long acrylic nails, immaculately painted with a different shade of polish on each finger. Her hair is freshly

\footnotetext{
${ }^{8}$ This episode can be watched at: https://www.youtube.com/watch?v=Y3NM2IwiGSg

${ }^{9}$ Watchable at the time of writing at: http://www.channel5.com/shows/benefits-britain-life-on-thedole/episodes/episode-6-470
} 
braided and her manicured hands glitter with enormous rings.' (Kite, 2013) To the sins of idleness are added those of vanity and greed, it is implied.

Nick and Margaret: We All Pay your Benefits encourages the 'taxpayers' who are paired with the claimants in their series to pass judgement on their lifestyles, prompted by questions like 'Do you think it is right for taxpayers to pay for people to keep pets?'. Unlike Saints and Scroungers in which sinful claimants are indirectly compared by a narrator with saintly ones, in order to emphasise their sinfulness, this programme confronts them directly with saintly workers, enabling the critical viewer to get a closer look at the constituents of saintliness. One episode ${ }^{10}$ featured a care-worker married to a truck driver working night shifts. Both worked long hours and they were shown, exhausted, handing over the childcare as one returned from work and the other departed, with barely time to exchange a few words. Their combined income, we were told, even including tax credit, was little more than the benefit paid to the idle claimants with whom they were compared. Their saintliness lay in their uncomplaining willingness to work long hours for low pay and demonstrate commitment to clients and employers. These are not the virtues of entrepreneurship, independence and competitiveness celebrated by Nick and Margaret in The Apprentice. Indeed some might regard them as their very opposite, even, perhaps, think that the workers are suckers for putting up with the situation. This message actually flies in the face of the logic of rationality that underlies neoliberal celebrations of the market. To a disinterested observer, it might seem quite rational that some unemployed people might have reservations about sacrificing their health and family life to enter such a labour market. But when such views are expressed by claimants in these programmes this is presented as more evidence of greed and idleness. Any expression by a claimant of some entitlement to a decent life is challenged, but what is never challenged is the nature of the labour market, presented as an unstoppable, unchangeable economic reality. At no point is it suggested, for instance, that the social problem which is actually being presented in this programme (the intolerable pressures of low-paid work on the daily life of the poor) might be solved by other means, for instance, by increasing pay or reducing working hours (although such a solution might actually create some extra jobs for the unemployed people presented in this programme, many of whom had actually made strenuous efforts to find work). In one extraordinary clip from this series, which has made it onto Youtube ${ }^{11}$, Nick Hewer is shown hectoring the unemployed father of a teenage son in an exchange that deserves to be quoted in full:

Nick Hewer (speaking as commentator, while camera pans along the faces of the family): Maybe we can understand kids like Kerry by looking at his family - Dad unemployed, Mum depressed beyond tablets. You want to help these people but the truth is they've got to help themselves.

$\mathbf{N H}$ (interviewing the father): Do you agree with this question: 'If you don't get a job (NH's jabbing finger comes into shot, pointing at the son) he gets stuffed'.

Claimant: The point is I'm trying to get a job. It's not as if I'm not trying to get a job ...

$\mathbf{N H}$ (interrupting): You must try harder.

\footnotetext{
${ }^{10}$ Unfortunately it is currently not possible to rewatch We All Pay Your Benefits at the time of writing so I am reliant on my memory for details. It is possible that I have conflated two episodes into one here.

${ }^{11} \mathrm{https}: / /$ www.youtube.com/watch?v=asL-vuXzP_o
} 
Claimant: I am trying. I'm doing...

NH (interrupting): Yes, but really hard.

Claimant: I am trying very hard but...

NH (interrupting): But couldn't you go round to somebody's house and just clean up?

Claimant: Clean up? Clean up somebody's house?

NH: Yes. And then ask for money for it.

Claimant: Yes I could do that.

NH: Why not do that tomorrow.

Claimant: All right. I..

$\mathbf{N H}$ (interrupting, with the air of someone who has scored a decisive victory): Good, thanks for talking to us.

When faced with the reality of the lack of legitimate work available, Hewer, (perhaps harking back to some kind of boy-scout experience in the development of his own career as an entrepreneur) resorts to recommending the sort of informal economic activity that would probably put the claimant in breach both of the conditions of his benefit and of labour market regulations.

This represents an impasse for neoliberal thinking. It is obvious that the entrepreneurial path can never provide a livelihood for the majority of working class people. Instead, they have to be coerced into accepting low-paid unrewarding jobs. But, in a model that claims that people are motivated only by the quest for personal reward, how can they be obliged to do so? Where, actually, in secular reality, is the reward for saintly hard work and self-sacrifice?

This can only be answered symbolically by the introduction of a benign Deus ex Machina, an allseeing authority who, unbeknownst to the worker, witnesses virtuous behaviour and rewards it. In the world of factual daytime television, this resolution is provided by Undercover Boss, a USoriginated programme in which CEOs of large companies go undercover in the firms they direct, in order to root out the sources of problems. The purpose of this exercise is always to improve the performance of the company, an aim whose rightness is never questioned. As the boss's progress unfolds (particularly in the US versions of the show, which are shown on British television) encounters are made with employees, many of whom are presented as saints (but with a few sinners thrown in for dramatic contrast). Viewers are provided with back stories for these saintly employees, featuring heart-tugging details (a disabled child, a parent with Alzheimers, a past living rough on the streets, a tragic bereavement, dedicated voluntary work for a charity) who are shown uncomplainingly and cheerfully and competently carrying out their work, often throwing in suggestions for how processes could be approved. In a final denouement, a symbolic Heaven, the boss's identity is revealed and, amidst tears and gratitude, rewards are bestowed for this saintly behaviour (a paid-for holiday, a promotion, a trust fund for the child to attend college, a donation to the charity). Long hours and low pay often feature in these programmes to, but no collective 
solution to them is ever proposed: the reward, the result of the employer's munificence, is bestowed randomly on a single individual rather than collectively or fairly.

\section{Conclusion}

What do we learn from these combined messages? Most obviously, they provide abundant evidence of the hegemonic sway of neoliberal attitudes: the rule of market rationality and the need for ruthless individual competition are presented as incontrovertible necessities, while narratives promoting alternative values such as solidarity, fairness and entitlement are silenced. The ideal worker they construct is well suited to the needs of a globalised economy. This is a worker who competes as an individual against other workers, prepared to step in and out of a variety of different low-paid roles in atomised and precarious labour markets and, furthermore, is prepared to sacrifice family life, sleep and health to serve the interests of the corporate employer, whose right to put profits first is unquestioned. To avoid become an undeserving 'scrounger' or 'slacker', this worker must even consider entering the informal economy.

However these messages also expose profound contradictions at the heart of neoliberalism. On the one hand, all values are reduced to economic ones and economic rationality is presented as trumping all others. But, on the other, behaviours are expected that are strongly contrary to economic logic. Whereas Homo Economicus might well decide to grab as much benefit as possible, resort to crime or organise with other workers to ratchet up the price that can be obtained for labour and claw back more leisure time from the employer, the ideal workers portrayed in these programmes are required to show, altruistically, that they care about clients, customers and the fulfilment of corporate goals and welfare recipients are expected to show humility and gratitude to the rest of society which, in the fictitious persona of 'the taxpayer' is paying their meagre benefits.

In the broader world of the market, economic rationality holds sway, but at the level of the household, the individual and the workplace, it is subordinated to a moral rationality. And this moral rationality requires both a sacrifice of self-interest and an identification with the interests of others. Just as the tenant, watching the property programme, is encouraged to identify with the economic interests of the landlord, so the worker must identify with the economic interests of the employer and the claimant with the economic interests of the taxpayer. Perceptions that this might be against one's own economic self interest are suppressed using moral arguments (you are greedy, selfindulgent, lazy etc.). In this neoliberal universe, appeals to abstract rules of fairness or equity are irrelevant, because authority is vested in 'experts'. Whether these are chat-show hosts, judges in a cookery contest, job appointments panels or doctors employed by a company commissioned by the state to determine your fitness for work, they make the decisions and that's that. You fail? Deal with it. This raises some important questions: With no possibility for direct expression, and no external legitimation, what happens to peoples' sense of unfairness? To what extent does providing them with scapegoats actually keep their anger under control? At what point do the tensions between the need to pursue self-interest and the imperative of self-sacrifice explode?

The discourses on saints and sinners in the media are bursting with such tensions, tensions whose connections with developments in the real world are under-explored. Might there, for instance, be a connection between the legitimisation of the demonisation of certain groups in society as 'scroungers' and the rise of right-wing political parties across Europe? What is the connection between the symbolically bulimic counterposition of eating and dieting, shopping and discarding, 
indulgence and self-discipline, construction and destruction, not just to actual incidences of eating disorders, self harm and anti-social behaviour but also to peoples' conflicted relationships with their own labouring bodies and the risks the are prepared to expose them to in the workplace? How do people reconcile conflicts between the urges to compete and to collaborate in labour markets that actually require both?

We can conclude that there is now an urgent need for deeper research into a range of different dimensions of the complex inter-relationship between television representations of work and unemployment and the lived experience of working people in the aftermath of economic crisis.

(C) Ursula Huws, 2014

\section{References:}

Ault, S. (2001) 'Who Watches Daytime?'. Accessed on August 15, 2014 from

http://www.broadcastingcable.com/news/news-articles/who-watches-daytime/96090

BARB (2013) The Viewing report, BARB, Broadcasters' Audience Research Board, November 2013

BBC News (2010)' Benefit fraud: Cameron defends use of credit rate firms', 10 August, Accessed on August 14, 2014 from: http://www.bbc.co.uk/news/uk-10922261

Bodenlos, J.S. \& Wormuth, B.M (2013) 'Watching a food-related television show and calorific intake. A laboratory study', Appetite, 61: 8-12

Bureau of Labor Statistics (2013) Time Use Survey, 2013, Washington D.C.: US Department of Labour. Accessed on August 12, 2014 from: http://www.bls.gov/news.release/atus.t11.htm

Channel 4 (2014). 'Benefits Street'. Accessed on August 19, 2014 from:

http://www.channel4.com/programmes/benefits-street

Clery, E., Lucy Lee and Sarah Kunz (2013) Public attitudes to poverty and welfare, 1983-2011:

Analysis using British Social Attitudes data, Joseph Rowntree Foundation. Accessed on August 12, 2014 from: http://www.natcen.ac.uk/media/137637/poverty-and-welfare.pdf

Collier, H. (2014) 'Channel 4's Benefits Street claims 4.3 million viewers', Guardian, January $7^{\text {th }}$. Accessed on August 15, 2014 from: http://www.theguardian.com/media/2014/jan/07/tvratingschannel4

Ditto, 2014 http://stakeholders.ofcom.org.uk/market-data-research/market-data/communicationsmarket-reports/cmr14/

Duffy, S. (2013) A fair society? How the cuts target disabled people, London: Centre for Welfare Reform. Accessed on August 20, 2014 from:

http://www.centreforwelfarereform.org/uploads/attachment/354/a-fair-society.pdf

Guardian (2011) 'England's housing market - how many of us own, rent or have a mortgage?', July 5. Accessed on August 20, 2014 from:

http://www.theguardian.com/news/datablog/2011/jul/05/housing-market-england\#data 
Guardian (2013) 'UK welfare spending: how much does each benefit really cost?', Guardian, January $8^{\text {th }}$. Accessed on JFebruary 7, 2013 from:

http://www.theguardian.com/news/datablog/2013/jan/08/uk-benefit-welfare-spending.

Hall, Stuart. Encoding and Decoding in the Television Discourse. Birmingham, England: Centre for Cultural Studies, University of Birmingham, 1973. 507-17.

Hernstein, R.J. \& C. Murray (1994) Bell Curve: Intelligence and Class Structure in American Life, Free Press.

HM Customs and Revenue, (2012) Child and Working Tax Credits Statistics, HMRC. Accessed on August 15, 2014 from:

http://webarchive.nationalarchives.gov.uk/20140507223936/http://www.hmrc.gov.uk/statistics/pr ov-main-stats/cwtc-apr12.pdf

Ipsos Mori Social Research Institute (2013) Child Hunger in London, Greater London Association. Accessed on August 12, 2014 from: https://www.london.gov.uk/priorities/businesseconomy/working-in-partnership/london-food-board/child-hunger-in-london

Kelly, B., J.C.G Halford, E.J. Bouyland, K. Chapman, I. Bautista-Castano, C. Berg, M. Caroli, B. Cookk, J.G. Coutinho, T. Effertz, E. Grammatikaki, K. Keller, R. Leung, Y. Manios, R. Monteiro, C. Pedley, H. Prell, K. Raine, E. Recine, L. Serra-Majem, S. Singh \& C. Summerbell (2010), 'Television Food Advertising to Children: A Global Perspective, American Journal of Public Health, 100 (9) 1730-1736

Kite, M. (2013) 'The extraordinary experiment that PROVES the welfare state has lost its way: Documentary challenged benefit claimants to live on 1949 handouts. The results will astonish and infuriate you', Daily Mail, 11 August. Accessed on August 12, 2014 from:

http://www.dailymail.co.uk/news/article-2389525/Channel-4-series-documents-extraordinaryexperiment-PROVES-welfare-state-lost-way.html

Marx, K (854) The German Ideology. Accessed on April 23, 2014 from: http://marxists.org/archive/marx/works/1845/german-ideology/ch01.htm

Nielsen (2012) Television Audience, 2010 \& 2011. Accessed on August $14^{\text {th }}, 2014$ from: http://robertoigarza.files.wordpress.com/2008/10/rep-television-audience-2010-11-nielsen2011.pdf

OFCOM, The Communications Market, 2013, Part 2 Television and audio-visual, 2013, London: OFCOM.

ONS (2013) 'Real Wages fall back to 2003 levels', Press Release, February $13^{\text {th }}$, Office of National Statistics. Accessed on August 19, 2014 from: http://www.ons.gov.uk/ons/dcp29904_299754.pdf

ONS (2014) Analysis of Employee Contracts that do not Guarantee a Minimum Number of Hours. London: Office of National Statistics, 30 April. Accessed on August 20, 2014 from:

http://www.ons.gov.uk/ons/dcp171776_361578.pdf

Seddon, C. (2011) 'Lifestyles and social participation', SocialTrends 41, London: Office of National Statistics. 'Daytime \& Early Peak on BBC One'. Accessed on August 15 th 2014 from: 
http://www.bbc.co.uk/commissioning/briefs/tv/browse-by-genre/daytime/daytime-early-peak-onbbc-one.shtml

Shimizu, M \& B. Wanskik (2011) 'Watching food-related television increases calorific intake in restrained eaters', Appetite, 57 (3): 661-664

Shute, J. (2013) 'Welfare reform: $£ 53$ a week... You do the maths' Daily Telegraph, 5 April. Accessed on August 15, 2014 from: http://www.telegraph.co.uk/news/politics/9974373/Welfare-reform-53-aweek...-You-do-the-maths.html

Standing, G. (2011) The Precariat: The New Dangerous Class, London: Bloomsbury

Thinkbox (2014) '98.5\% of TV was watched on a TV set in 2013'. Accessed on August 15, 2014 from http://www.thinkbox.tv/98.5-of-tv-was-watched-on-a-tv-set-in-2013

Tressell Trust (2014) 'The Trussell Trust's UK foodbank network'. Accessed on August 16, 2014 from: http://www.trusselltrust.org/resources/documents/Press/TT-Foodbank-Information-Pack-201314.pdf

Tressider, R. (2010) 'Reading food marketing: the semiotics of Marks \& Spencer!?', International Journal of Sociology and Social Policy 30 (9/10):472-485 